\title{
ОСОБЛИВОСТІ ЛОКАЛЬНИХ ІМУННИХ РЕАКЦІЙ У ДВАНАДЦЯТИПАЛІЙ КИШЦІ ПРИ ПОСТРЕЗЕКЦІЙНІЙ ПОРТАЛЬНІЙ ГІПЕРТЕНЗІї
}

\author{
ОМ. С. Гнатюк, Л. В. Татарчук \\ ДВНЗ «Тернопільський державний медичний університет імені І. Я. Горбачевського МОз України»
}

РЕзЮМЕ. Резекція великих об'ємів печінки може призводити до різних пострезекційних ускладнень: кровотечі з варикозно розширених вен стравоходу, шлунка, прямої кишки, асциту, спленомегалії, вторинного гіперспленізму, паренхіматозної жовтяниці, портосистемної енцефалопатії, печінкової недостатності, портальної гіпертензії. Пострезекційна портальна гіпертензія призводить до структурної перебудови органів басейну ворітної печінкової вени, а також ремоделювання їх структур. Венозний дренаж від дванадцятипалої кишки здійснюється через ворітну печінкову вену, де гемодинамічні розлади ускладнюються різними морфологічними змінами у судинах та структурах вказаного органа. Особливості локального імунного захисту дванадцятипалої кишки при пострезекційній портальній гіпертензії вивчені недостатньо.

Мета - дослідити особливості локальних імунних реакцій у дванадцятипалій кишці при пострезекційній портальній гіпертензії.

Матеріал і методи. Дослідження проведені на 45 щурах-самцях, які були поділені на 3 групи. До 1 групи увійшли 15 інтактних тварин, до 2 - 15 щурів після резекції лівої бокової частки (31,5 \% паренхіми печінки), до 3 12 тварин після резекції правої та лівої бокових часток печінки (58,1% паренхіми печінки). Евтаназію тварин здійснювали кровопусканням в умовах тіопентал-натрієвого наркозу через 1 місяць від початку експерименту. Вирізані шматочки із дванадцятипалої кишки фіксували в 10 \% нейтральному розчині формаліну і, після відповідного проведення через етилові спирти зростаючої концентрації, заливали у парафінові блоки. Гістологічні зрізи товщиною 5-7 мкм після депарафінізації фарбували гематоксиліном-еозином, за ван-Гізон, Маллорі, Вейгертом, толуїдиновим синім. При виявленні плазматичних клітин-продуцентів Ig A, lg M, lg G, Ig E мікротомні зрізи дванадцятипалої кишки обробляли моноспецифічними антисироватками проти вказаних класів імуноглобулінів, кон'югованими із ізотіоціанатом флуоресцеїну, застосовуючи прямий метод Кунса з відповідними контролями, які вивчали за допомогою люмінесцентного мікроскопа «Люмам Р-8». У люмінесцентному світлі рахували плазматичні клітини, що давали специфічне світіння, на 1 мм² слизової оболонки досліджуваного органа. Вміст секреторного Ig A (SIgA) визначали методом роздільної імунодифузії в агарі з специфічною сироваткою проти SIgA. Кількісні показники обробляли статистично.

Результати. Через місяць після резекції 31,5 \% паренхіми печінки локальні імунні реакції у слизовій оболонці дванадцятипалої кишки змінилися незначно. Порушення локального імунного гомеостазу виявилося більш вираженим при резекції 58,1 \% об'єму печінки. Так, число плазматичних клітин з IgA у слизовій оболонці досліджуваного зменшилося на 26,6 \%, рівень секреторного імуноглобуліну А знизився на 27,9 \%, а рівні плазмоцитів-продуцентів IgM, IgG, IgE відповідно збільшилися на 97,0 \%, у 4,2 та 6,0 разів. Ступінь змін місцевого гомеостазу корелював із глибиною та поширеністю гемодинамічних розладів, дистрофічними, некробіотичними, інфільтративними та склеротичними процесами у досліджуваному органі, тобто йому належить важлива роль у морфогенезі дванадцятипалої кишки при пострезекційній портальній гіпертензії.

Висновки. Резекція 58,1 \% паренхіми печінки призводить до пострезекційної портальної гіпертензії та виражених змін локального імунного гомеостазу у слизовій оболонці дванадцятипалої кишки, які характеризуються зниженням рівнів SIgA і кількості плазмоцитів-продуцентів IgA, значними порушеннями співвідношень між імуноцитами, що синтезують $\mathrm{lgA}, \lg \mathrm{M}, \mathrm{IgG}, \lg \mathrm{E}$, появою імунних комплексів у стромі та судинах. Ступінь змін місцевих імунних реакцій корелює із глибиною та поширеністю гемодинамічних розладів, дистрофічними, некробіотичними, інфільтративними та склеротичними процесами у досліджуваному органі.

КлючОВІ СлОВА: резекція печінки; дванадцятипала кишка; локальний імунітет.

Вступ. На сьогодні у хірургічних клініках лікувальних закладів нерідко виконують резекцію печінки. Цю операцію здійснюють при доброякісних та злоякісних пухлинах, метастазах, травмах печінки, внутрішньопечінковому холангіолітіазі, альвеолярному ехінококозі, трансплантації печінки $[2,10,11]$. У сучасній медико-біологічній літературі зустрічаються публікації, у яких відображені результати експериментальних досліджень 3 вивчення паренхіми печінки при їі резекції. Водночас структурні зміни у травному каналі при вка- заних операціях досліджені недостатньо. Вирішення цього питання має не тільки важливе теоретичне значення, а й набуває актуальності у клінічній практиці.

Резекція великих об'ємів паренхіми печінки призводить до виникнення пострезекційної портальної гіпертензії та складних загальнобіологічних процесів, які виникають і розвиваються при цьому в органах і системах організму внаслідок його адаптації до нового рівня життєдіяльності [3, 10]. Компенсаторно-адаптаційні процеси у стінці 
Огляди літератури, оригінальні дослідження, погляд на проблему, ювілеї

дванадцятипалої кишки при резекціях різних об'ємів печінки, їх роль у розвитку ентеральної недостатності до сьогоднішнього дня досліджені недостатньо і потребують свого вирішення.

Мета - дослідити особливості локальних імунних реакцій у дванадцятипалій кишці при пострезекційній портальній гіпертензії.

Матеріал і методи дослідження. Дослідження проведені на 45 статевозрілих щурах-самцях, які були поділені на 3 групи. 1 група включала 15 інтактних практично здорових тварин, 2 - 15 щурів після резекції лівої бокової частки (31,5 \%), 3 12 тварин після резекції правої та лівої бокових часток печінки (58,1%). Евтаназію дослідних тварин здійснювали кровопусканням в умовах тіопентал-натрієвого наркозу через 1 місяць від початку експерименту. Вирізані шматочки із дванадцятипалої кишки фіксували в 10 \% нейтральному розчині формаліну і після відповідного проведення через етилові спирти зростаючої концентрації заливали у парафінові блоки за загальноприйнятою методикою. Гістологічні зрізи товщиною 5-7 мкм після депарафінізації фарбували гематоксиліномеозином, за ван-Гізон, Маллорі, Вейгертом, толуїдиновим синім [9]. При виявленні плазматичних клітин-продуцентів Ig A, Ig M, Ig G, Ig Е мікротомні зрізи дванадцятипалої кишки обробляли моноспецифічними антисироватками проти вказаних класів імуноглобулінів, кон'югованими із ізотіоціанатом флуоресцеїну, застосовуючи прямий метод Кунса з відповідними контролями $[4,6]$, які вивчали за допомогою люмінесцентного мікроскопу «Люмам Р-8». У люмінесцентному світлі підраховували плазматичні клітини, що давали специфічне світіння, на 1 мм² слизової оболонки досліджува- ного органа [1]. Вміст секреторного Ig A (SIgA) визначали методом роздільної імунодифузії в агарі з специфічною сироваткою проти SIgA [6]. Експериментальні дослідження та евтаназію дослідних тварин проводили із дотриманням "Загальних етичних принципів експериментів на тваринах", ухвалених Першим національним конгресом з біоетики (Київ, 2001) та відповідно до "Європейської конвенції про захист хребетних тварин, що використовуються в дослідних та інших наукових цілях" [5]. Кількісні показники обробляли статистично. Обробка результатів виконана у відділі системних статистичних досліджень ДВНЗ «Тернопільський державний медичний університет імені І. Я. Горбачевського МОЗ України» в програмному пакеті Statistica ("StatSoft Inc.», США). Різницю між порівнюваними величинами визначали за критерієм Стьюдента та Манна-Уїтні [1, 7].

Результати й обговорення. Дані, отримані в результаті проведеного дослідження, показані в таблиці 1. В результаті всестороннього аналізу показників, наведених у таблиці, встановлено, що через місяць після резекції 31,5 \% паренхіми печінки вони змінювалися незначно. Число плазматичних клітин з IgA у слизовій оболонці дванадцятипалої кишки зменшилося $3(206,4 \pm 2,1)$ до $(194,2 \pm 2,4)$. Між наведеними показниками виявлена статистично достовірна $(p<0,05)$ різниця, остання цифрова величина виявилася меншою за попередню на 5,9\%. Кількість плазмоцитів з IgM у даних умовах експерименту збільшилася на 4,2 \%, з IgG - на 8,2 \%, а 3 $\mathrm{lgE}$ - на 15,8 \%. Концентрація секреторного імуноглобуліну А при цьому з статистчно достовірною різницею $(p<0,05)$ зменшилася з $(0,624 \pm 0,009)$ г/л до $(0,592 \pm 0,009)$ г/л, тобто на $5,1 \%$.

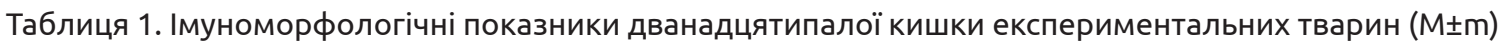

\begin{tabular}{|l|c|c|c|}
\hline \multirow{2}{*}{ Показник } & \multicolumn{3}{|c|}{ Група тварин } \\
\cline { 2 - 4 } & 1 -а & 2 -а & 3-я \\
\hline Плазматичні клітини з IgA & $206,4 \pm 2,1$ & $194,2 \pm 2,4^{*}$ & $205,9 \pm 3,3^{* * *}$ \\
\hline Плазматичні клітини 3 IgM & $104,5 \pm 1,6$ & $108,9 \pm 1,5^{*}$ & $218,8 \pm 2.7^{* * *}$ \\
\hline Плазматичні клітини 3 IgG & $52,1 \pm 0,6$ & $56,4 \pm 0,6^{* *}$ & $82,9 \pm 1,2^{* * *}$ \\
\hline Плазматичні клітини 3 IgE & $13,90 \pm 0,21$ & $16,10 \pm 0,24^{* *}$ & $0,450 \pm 0,012^{* * *}$ \\
\hline SIgA, г/л & $0,624 \pm 0,009$ & $0,592 \pm 0,009^{*}$ & \\
\hline
\end{tabular}

Примітка. * $-p<0,05 ; * *-p<0,01 ; * * *-p<0,001$ порівняно з 1 групою спостережень.

У дослідних тварин через місяць після резекції 58,1 \% паренхіми печінки при розтині очеревинної порожнини спостерігалося розширення печінкової ворітної вени, повнокров'я і розширення брижових вен та видимого венозного русла тонкої та товстої кишок. Слизова оболонка дванадцятипалої кишки повнокровна, набрякла, з поодинокими осередками точкових крововили- вів. Описане вище свідчило про наявність пострезекційної портальної гіпертензії [3].

Досліджувані локальні імунні реакції у слизовій оболонці дванадцятипалої кишки при цьому виявилися більш вираженими, порівняно з попередніми. Так, число плазматичних клітин з IgA у слизовій оболонці досліджуваного органа з вираженою статистично достовірною різницею $(p<0,001)$ 
Огляди літератури, оригінальні дослідження, погляд на проблему, ювілеї

зменшилося на 26,6 \%, а плазмоцити-продуценти IgM, IgG, IgE відповідно збільшилися на 97,0 \%, у 4,2 та 6,0 разів. Рівень секреторного імуноглобуліну A з високим ступенем статистичної достовірності $(p<0,001)$ зменшився з $(0,624 \pm 0,009)$ до $(0,450 \pm 0,012)$ г/л, тобто на $27,9 \%$.

Відомо, що важливою ланкою локального імунного гомеостазу слизових оболонок шлунково-кишкового тракту та дихальних шляхів $\in$ SIgA, який забезпечує «першу лінію захисту» вказаних структур від пошкоджуючих агентів. Виражене зниження рівня SIgA при пострезекцій портальній гіпертензії, тобто через місяць після резекції 58,1 \% паренхіми печінки, свідчить про значне пошкодження цього імунного захисту. Зростання при цьому плазмоцитів-продуцентів IgM, IgG, IgE, виражене порушення співвідношень між ними вказувало на напруженість та нестабільність локальних імунних реакцій у слизовій оболонці дванадцятипалої кишки [6].

Необхідно також зазначити, що переважна більшість імунокомпетентних клітин локалізувалася у поверхневих ділянках слизової оболонки дванадцятипалої кишки. Серед них виявляли Т-лімфоцити, що відповідають за специфічну антигенну стимуляцію, беруть участь в реакціях підвищеної чутливості сповільненого типу, підвищують активність макрофагів шляхом взаємодії $з$ попередниками антитілоутворюючих клітин, а також плазмоцити, які виникають з В-лімфоцитів і беруть активну участь у імунних реакціях, завдяки властивості синтезувати білки-імуноглобуліни. У слизовій оболонці дванадцятипалої кишки та її власній пластинці з'являлися імунні комплекси і дегранульовані тканинні базофіли. Імунні комплекси, а також IgM та IgG, фіксувалися у стінках гемокапілярів, кровоносних судин.

При гістологічному дослідженні мікропрепаратів дванадцятипалої кишки, переважно у 3-й групі спостережень, спостерігалися виражені судинні розлади (повнокров'я переважно венозних судин, явища перивазального набряку, стази у венозній частині мікрогемоциркуляторного русла, осередки діапедезних крововиливів), дистрофічні, некробіотичні зміни епітеліоцитів, ендотеліоцитів, стромальних структур, інфільтративні та склеротичні процеси. Домінували описані патогістологічні зміни у стінці досліджуваного органа через місяць після резекції 58,1 \% паренхіми печінки. Варто також зазначити, що виявлені патогістологічні ушкодження стінки дванадцятипалої кишки при резекції печінки корелювали з досліджуваними імуногістологічними показниками. При значних відхиленнях імуногістохімічних параметрів дванадцятипалої кишки від контрольних величин у оболонках досліджуваного органа спостерігалися більш виражені та розповсюджені патогістологічні процеси. Існує думка, що напруженість та виражені зміни імуногого захисту слизових оболонок травного тракту призводять до суттєвих порушень тканинного та клітинного структурного гомеостазів [8]. Отримані дані свідчать, що локальні імунні процеси відіграють важливу роль у морфогенезі дванадцятипалої кишки при тривалій пострезекційній портальній гіпертензії.

Висновки. Резекція 58,1 \% паренхіми печінки призводить до пострезекційної портальної гіпертензії та виражених порушень локального імунного гомеостазу у слизовій оболонці дванадцятипалої кишки, які характеризуються зниженням рівнів SIgA і кількості плазмоцитів-продуцентів IgA, значними порушеннями співвідношень між імуноцитами, що синтезують імуноглобуліни IgA, IgM, IgG, $\mathrm{lgE}$, появою імунних комплексів у стромі та судинах. Ступінь змін місцевих імунних реакцій корелює із глибиною та поширеністю гемодинамічних розладів, дистрофічними, некробіотичними, інфільтративними та склеротичними процесами у досліджуваному органі.

Перспективи подальших досліджень. Всебічне вивчення місцевого імунного гомеостазу дванадцятипалої кишки в умовах пострезекційної портальної гіпертензії дозволить суттєво розширити діагностику, корекцію та профілактику досліджуваної патології.

\section{ЛІТЕРАТУРА}

1. Автандилов Г. Г. Основы количественной патологической анатомии. - М. : Медицина, 2002. - 240 с.

2. Вишневський В. А. Сегментарные резекции, отдаленные результаты при злокачественных опухолях печени / В. А. Вишневский, М. Г. Ефанов, И. В. Казаков // Укр. журнал хірургії. - 2012. - № 1 (16). - С. 5-15.

3. Гнатюк М. С. Морфометрична оцінка особливостей ремоделювання структур дванадцятипалої кишки при резекції різних об'ємів печінки / М. С. Гнатюк, Л. В. Татарчук, О. Б. Ясіновський // Науковий вісник Ужго- родського університету. Серія «Медицина». - 2016. вип. (53). - С. 92-95.

4. Гнатюк М. С. Біохімічні та імунологічні аспекти в патогенезі уражень клубової кишки при отруєнні блідою поганкою / М. С. Гнатюк, Л. Т. Виклюк // Медична хімія. - 2003. - № 3. - С.72-75.

5. Загальні етичні принципи експериментів на тваринах // Ендокринологія. - 2003. - Т. 8, № 1. - С. 142-145.

6. Кімакович В. Й. Імунна система шлунково-кишкового тракту в нормі та патології / В. Й. Кімакович, 
Огляди літератури, оригінальні дослідження, погляд на проблему, ювілеї

В. В. Чоп'як, О. В. Бродик. - Тернопіль : Укрмедкнига, 1999. $-100 \mathrm{c}$.

7. Лапач С. Н. Статистические методы в медикобиологических исследованиях Excell / C. Н. Лапач, А. В. Губенко, П. Н. Бабич. - К. : Морион, 2001. - 410 с.

8. Саркисов Д. С. Структурне основы адаптации и компенсации нарушенных функций / Д. С. Саркисов. М. : Медицина, 1998. - 230 с.

9. Сорочинников А. Г. Гистологическая и микроскопическая техника / А. Г. Сорочинников, А.Е. Доросевич.М. : Медицина. - 2007. - 448 с.
10. Федоров В. Д. Основные осложнения обширных резекций печени и пути их предупреждения / В. Д. Федоров, В. А. Вишневский, Н. А. Назаренко [и др.] // Бюлл. сибирской медицины. - 2007. - № 4. - С. 16-24.

11. Nanashima A. A modified grading system for posthepatectomy metastatic liver cancer originating form colorectal carcinoma / A. Nanashima, Y. Sumida, T. Abo // J. Surg. Oncol. - 2008. - No. 98. - P. 363-370.

\title{
REFERENCES
}

1. Avtadilov, G.G. (2002). Osnovy kolichestvennoy patologicheskoy anatomii [Basis of quantitative pathological anatomy]. Moscow: Meditsina [in Russian].

2. Vishnevskiy, V.A., Yefanov, M.G., \& Kazakov, I.V. (2012). Segmentarnyye rezektsyi, otdalennyye rezultaty pri zlokachestvennykh opukholyakh pecheni [Segmentar resections, long-term results in malignant liver tumors]. Ukr. Zhurnal khirurgii - Ukrainian Journal of Surgery, 1 (16), 5-15 [in Ukrainian].

3. Hnatiuk, M.S., Tatarchuk, L.V., \& Yasinovskyi, O.B. (2016). Morfometrychna otsinka osoblyvostei remodeliuvania struktur dvanadtsiatypaloi kyshky pry resektsii riznykh obiemiv pechinky [Morphometric evaluation of the features of remodeling of duodenal structures at resection of different volumes of the liver]. Naukovyi visnyk Uzhhorodskoho universytetu. Seriia "Medytsyna" - Scientific Herald of Uzhhorod University. Series "Medicine", 1 (49), 3-5 [in Ukrainian].

4. Hnatiuk, M.S., \& Vykliuk, L.T. (2003). Biokhimichni ta imunolohichni aspekty $v$ patohenezi urazhen klubovoi kyshky pry otruienni blidoiu pohankoiu [Biochemical and immunological aspects ileum at poisoning of amanita phallpides]. Medychna khimiia - Medical Chemistry, 3, 72-75 [in Ukrainian].

5. (2003). Zahalni etychni pryntsypy eksperymentiv na tvarynakh [General ethical principles of experiments on animals]. Endokrynolohiia - Endocrinology, 8, 1, 142-145 [in Ukrainian].

6. Kimakovych, V.Y., Chopiak, V.V., \& Brodyk, O.V. (1999). Imunna systema shlunkovo-kyshkovoho traktu $v$ normi ta patolohii [Immune system of gastrointestinal tract in norm and pathology]. Ternopil; Ukrmedknyha [in Ukrainian].

7. Lapach, S.N., Gubenko, A.V., \& Babich, P.N. (2001). Statistichieskiye metody $v$ mediko-biologicheskikh issledovaniyakh Excell [Statistical methods in medicobiological investigations Excell]. Kyiv: Morion [in Ukrainian].

8. Sarkisov, D.S. (1998). Strukturnyye osnovy adaptatsyi i kompensatsyi narushennykh funktsyy [Structural basis adaptation and compensation damage function]. Moscow: Meditsina [in Russian].

9. Sorochinnikov, A.G., \& Dorosevich, A.Ye. (2007). Gistologichieskaya i mikroskopicheskaya tekhnika [Histological and microscopic equipments]. Moscow: Meditsina [in Russian].

10. Fiodorov, V.D., Vishnevskiy, V.A., Nazarenko, N.A. (2007). Osnovnye oslozhneniya obshyrnykh rezektsyy pecheni i puti ikh preduprezhdeniya [The main complications of extensive liver resections and ways to prevent them]. Byull. Sibirskoy meditsyny-Bulletin of Siberian Medicine, 4, 16-24 [in Russian].

11. Nanashima A., Sumida, Y., \& Abo T.(2008). A modified grading system for post-hepatectomy metastatic liver cancer originating form colorectal carcinoma. J. Surg. Oncol., 98, 363-370.

\section{ОСОБЕННОСТИ ЛОКАЛЬНЫХ ИММУННЫХ РЕАКЦИЙ В ДВЕНАДЦАТИПЕРСТНОЙ КИШКЕ ПРИ ПОСТРЕЗЕКЦИОННОЙ ПОРТАЛЬНОЙ ГИПЕРТЕНЗИИ}

\author{
๑М. С. Гнатюк, Л. В. Татарчук
}

\section{ГВУз «Тернопольский государстивенный медицинский университет имени И. Я. Горбачевского} МЗ Украины»

РЕЗЮМЕ. Резекция больших объемов печени может приводить к разным пострезекционным осложнениям: кровотечениям из варикозно расширенных вен пищевода, желудка, прямой кишки, асциту, спленомегалии, вторичному гиперспленизму, паренхиматозной желтухе, портосистемной энцефалопатии, печеночной недостаточности, портальной гипертензии. Пострезекционная портальная гипертензия приводит к структурной перестройке органов бассейна воротной печеночной вены и ремоделированню их структур. Венозный дренаж от двенадцатиперстной кишки осуществляется воротной печеночной веной, где гемодинамические расстройства осложняются разными морфологическими изменениями в сосудах и структурах названного органа. Необходимо отметить, что особенности локальной иммунной защиты двенадцатиперстной кишки при пострезекционной портальной гипертензии изучены недостаточно. 
Цель - исследовать особенности локальных иммунных реакций в двенадцатиперстной кишке при пострезекционной портальной гипертензии.

Материал и методы. Исследования проведены на 45 крысах-самцах, которые были поделены на 3 группы: 1-я группа состояла из 15 интактных животных, 2-я - из 15 крыс после резекции левой боковой части - 31,5 \% паренхимы печени, 3-я - 12 животных после резекции правой и левой боковых частей печени - 58, $1 \%$ паренхимы печени. Эвтаназия животных осуществлялась кровопусканием в условиях тиопентал-натриевого наркоза через 1 месяц от начала эксперимента. Вырезанные кусочки из двенадцатиперстной кишки фиксировали в $10 \%$ нейтральном растворе формалина и после соответствующего проведення через этиловые спирты возрастающей концентрации заливали в парафиновые блоки. Гистологические срезы толщиной 5-7 мкм после депарафинизации красили гематоксилином-эозином, по ван Гизон, Маллори, Вейгерту, толуидиновым синим. При выявлении плазматических клеток-продуцентов Ig A, Ig M, Ig G, Ig E микротомные срезы двенадцатиперстной кишки обрабатывали моноспецифическими антисыворотками против указанных класов иммуноглобулинов, конъюгированными с изотиоцианатом флуоресцеина, применяя прямой метод Кунса с соответствующими контролями, которые изучали с помощью люминесцентного микроскопа «Люмам Р-8». В люминесцентном свете подсчитывали плазматические специфически

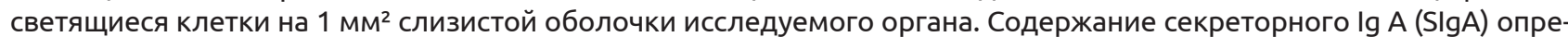
деляли методом раздельной иммунодиффузии в агаре со специфической сывороткой против SlgA. Количественные показатели обрабатывали статистически.

Результаты. Через месяц после резекции 31,5 \% паренхимы печени локальные иммунные реакции в слизистой оболочке двенадцатиперстной кишки изменялись незначительно. Нарушения локального иммунного гомеостаза оказались более выраженными при резекции 58,1 \% объема печени. Число плазматических клеток с IgA в слизистой оболочке исследуемого органа при этом уменьшилось на 26,6 \%, уровень секреторного иммуноглобулина А снизился на 27,9 \%, а плазмоциты-продуценты IgM, IgG, IgE соответственно увеличились на $97,0 \%$, в 4,2 та 6,0 раз. Степень изменений местного гомеостаза коррелировала с глубиной и распространением гемодинамических расстройств, дистрофическими, некробиотическими, инфильтративными и склеротическими процессами в исследуемом органе, то есть ему принадлежит важная роль в морфогенезе двенадцатиперстной кишки при пострезекционной портальной гипертензии.

Выводы. Резекция 58,1 \% паренхимы печени приводит к пострезекционной портальной гипертензии и выраженным изменениям локального иммунного гомеостаза в слизистой оболочке двенадцатиперстной кишки, которые характеризуются снижением уровней SIgA и количества плазмоцитов-продуцентов IgA, значительными нарушениями соотношений между иммуноцитами, которые синтезируют IgA, lgM, IgG, IgE, появлением иммунных комплексов в строме и сосудах. Степень изменений местных иммунных реакций коррелирует с глубиной и распространением гемодинамических расстройств, дистрофическими, некробиотическими, инфильтративными и склеротическими процессами в исследуемом органе.

КЛЮчЕВЫЕ СЛОВА: резекция печени; двенадцатиперстная кишка; локальный иммунитет.

\section{THE PECULIARITIES OF LOCAL IMMUNE REACTIONS IN DUODENUM AT POSTRESECTION PORTAL HYPERTENSION}

@M. S. Hnatiuk, L. V. Tatarchuk

\section{Horbachevsky Ternopil State Medical University}

SUMMARY. Resection of large volumes of the liver leads to various post-resection complications: hemorrhages of varicose veins of the esophagus, stomach, rectum, ascites, splenomegaly, secondary hypersplenism, parenchymal jaundice, porosystemic encephalopathy, liver failure, portal hypertension. Postrezectional portal hypertension leads to structural rearrangement of the organs of the basilar portal hepatic vein, as well as the remodeling of their structures. Venous drainage from the duodenum is carried out through the portal hepatic vein, where hemodynamic disorders are complicated by various morphological changes in the vessels and structures of the specified organ. It should be noted that the features of local immune defense of the duodenum at postresection portal hypertension are not sufficiently studied.

The aim - to investigate the features of local immune reactions in the duodenum at postresection portal hypertension.

Material and Methods. The research was conducted on 45 male rats, which were divided into 3 groups. The group 1 consisted of 15 intact animals, 2 - 15 rats after resection of the left lateral part - $31.5 \%$ of liver parenchyma, 3-15 animals after resection of the right and left side parts of the liver (58.1\%). Euthanasia of animals was carried out by bloodletting in conditions of thiopental anesthesia 1 month after the beginning of the experiment. The cut pieces of the duodenum were fixed in a $10 \%$ neutral formalin solution, and after appropriate ethyl alcohol of increasing concentration was poured in paraffin blocks. Histologic sections 5-7 $\mu \mathrm{m}$ thick after deparaffinization were stained with hematoxylin-eosin, for van Gizon, Mallory, Weigert, and toluidine blue. In the detection of plasmocytes with IgA, IgM, IgG, IgE histologic sections of the duodenum was treated with monospecific antiserrm against these classes of immunoglobulins conjugated with fluorescein isothiocyanate using the direct Kuns method with appropriate controls that were studied using a luminescent microscope "Lumam P-8". In a luminescent light, plasma cells that gave a specific 
Огляди літератури, оригінальні дослідження, погляд на проблему, ювілеї

luminescence were read on $1 \mathrm{~mm}^{2}$ of the mucosa of the investigated organ. The content of secretory lg A (SIgA) was determined by the method of separate immunodiffusion in agar with a specific serum against SIgA. Quantitative indicators were processed statistically.

Results. One month after resection of $31.5 \%$ of the liver, local immune reactions in the mucosa of the duodenum changed slightly. Violation of local immune homeostasis was more pronounced in resection of $58.1 \%$ of the liver volume. Thus, the number of plasmatic cells from IgA in the mucosa of the subject decreased by $26.6 \%$, the level of secretory immunoglobulin A decreased by $27.9 \%$. while the plasma-producing producers IgM, IgG, IgE increased accordingly by $97.0 \%, 4.2$ and 6.0 times. The degree of changes in local homeostasis correlated with the depth and prevalence of hemodynamic disorders, dystrophic, fibrotic, infiltrative and sclerotic processes in the investigated organ, that is, it plays an important role in the morphogenesis of the duodenum in postresection portal hypertension.

Conclusions. Resection of $58.1 \%$ of liver parenchyma leads to postresection portal hypertension and pronounced changes in local immune homeostasis in the duodenal mucosa, characterized by a decrease in the levels of SIgA and the number of IgA-producing plasmocytes, significant violations of the correlation between the immunocytes that synthesize IgA, IgM, IgG, IgE, the emergence of immune complexes in the stroma and vessels. The degree of changes in local immunity correlates with the depth and prevalence of hemodynamic disorders, dystrophic, fibrotic, infiltrative and sclerotic processes in the investigated organ.

KEY WORDS: resection of liver; duodenum; local immunity. 